\title{
PENINGKATAN KUALITAS PENDIDIKAN UNTUK ANAK SUKU ANAK DALAM DI DUSUN SELAPIK, KABUPATEN MUARO JAMBI
}

\author{
Revis Asra' ${ }^{1}$, M. Naswir ${ }^{2}$, U. Kalsum ${ }^{3}$, Syaparuddin ${ }^{4}$, dan A. Puji Lestari ${ }^{5}$ \\ ${ }^{1}$ Prodi Biologi, Fakultas Sains dan Teknologi, Universitas Jambi \\ Kampus Pinang Masak, Jalan Jambi-Muara Bulian KM. 15 Mendalo Darat, Jambi 36361 \\ ${ }^{2}$ Prodi Kimia, Fakultas Sains dan Teknologi, Universitas Jambi \\ ${ }^{3}$ Fakultas Kesehatan Masyarakat, Universitas Jambi \\ ${ }^{4}$ Fakultas Ekonomi dan Bisnis Universitas Jambi \\ ${ }^{5}$ Fakultas Pertanian, Universitas Jambi \\ Email: revisasra@unja.ac.id; m.naswir@yahoo.co.id; ummi2103@gmail.com
}

\begin{abstract}
ABSTRAK
Dusun Selapik merupakan salah satu dusun yang masuk ke dalam Desa Nyogan Kecamatan Mestong, Kabupaten Muaro Jambi. Dusun ini merupakan tempat bermukimnya Suku Anak Dalam (SAD), yang hidup berdampingan dengan warga desa lainnya. Suku Anak Dalam di Dusun Selapik sudah bermukim permanen di kawasan dekat dengan pemukiman penduduk biasa, dan tidak berpindah-pindah, seperti kebiasaan SAD lainnya. Pendidikan bagi anak-anak Suku Anak Dalam yang berada di Dusun Selapik tidak mengikuti sekolah formal sama sekali, mereka hanya belajar di sanggar belajar "Meraih Mimpi". Sanggar Belajar ini dibina oleh Karang Taruna Setempat, dan waktu belajarnya hanya 3 kali seminggu, dengan fasilitas seadanya. Berdasarkan hasil survey pendahuluan dan wawancara langsung dengan kepala Dusun Selapik diperoleh informasi bahwa masalah biaya merupakan penyebab utama yang menyebabkan anak-anak SAD putus sekolah. Universitas Jambi sebagai salah satu Lembaaga Pendidikan dan merupakan Perguruan Tinggi Negeri terbesar di Provinsi Jambi, melalui Pusat Sudi Pendidikan Masyarakat dibawah Lembaga Penelitian dan Pengabdian Masyarakat turut terpanggil untuk melakasanakan program pendidikan untuk anak-anak SAD. Metode pengabdian yang digunakan yaitu Participatory Rural Apraisal (PRA), yaitu metode pendidikan pada masyarakat.Berdasarkan hasil kegiatan Pengabdian Kepada Masyarakat tentang Peningkatan Kualitas Pendidikan untuk Suku Anak Dalam di Dusun Selapik dapat diambil kesimpulan: (1).Sosialisasi kepada Kepala Desa dan Aparat Desa telah dilakukan dalam upaya untuk mengetahui kondisi real masyarakat Dusun Selapik. (2). Penyuluhan kepada Orangtua SAD telah menggugah dan menyadarkan mereka akan pentingnya pendidikan untuk anak-anak mereka, (3) Pemberian bantuan sarana dan prasarana pendidikan kepada anak-anak SAD meningkatkan pemahaman anak-anak dalam belajar, mengaji dan praktek ibadah, (4) Kemajuan pendidikan anak-anak SAD di Dusun Selapik cukup signifikan dengan adanya kegiatan Pengabdian Masyarakat ini.
\end{abstract}

\section{Kata Kunci: Pendidikan, Anak SAD, Dusun Selapik}

\section{PENDAHULUAN}

Dusun Selapik merupakan salah satu dusun yang terdapat di Desa Nyogan di Kecamatan Mestong, Kabupaten Muaro Jambi. Dusun ini memiliki salah satu keunikan, dimana $50 \%$ dari jumlah penduduknya adalah Suku Anak Dalam (SAD), yang hidup berdampingan dengan warga desa. Suku Anak Dalam yang bermukim di Dusun Selapik sudah bermukim permanen di kawasan dekat dengan pemukiman penduduk biasa, dan tidak berpindah-pindah, seperti kebiasaan SAD lainnya. Kehidupan yang unik dan eksotik merupakan sebab kepopuleran 
mereka. Ditengah modernisasi yang berkembang pesat, mereka masih saja terkungkung dalam kehidupan seperti yang dilaksanakan nenek moyangnya. Oleh sebab itu SAD masih dianggap primitive (Baharudin, 2010).

Anak-anak SAD di Dusun Selapik tidak mengikuti sekolah formal sama sekali, mereka hanya belajar di sanggar belajar "Meraih Mimpi". Sanggar Belajar ini dibina oleh Karang Taruna Setempat, dan waktu belajarnya hanya 3 kali seminggu, pada jam 16 -18 WIB dengan fasilitas seadanya.

Berdasarkan hasil survey pendahuluan dan wawancara langsung dengan kepala Dusun diperoleh informasi bahwa masalah biaya merupakan penyebab utama yang menyebabkan anak-anak SAD tidak bersekolah. Berdasarkan hasil penelitian Rahmawanta (2013) pada Suku Dayak bahwa keadaan sosial ekonomi kurang mendukung untuk membiayai pendidikan menyebabkan anak-anak putus sekolah, orang tua lebih suka menyuruh anaknya bekerja membantu orang tuanya, serta pada umumnya orang tua masih memandang keliru terhadap arti penting pendidikan bagi kepentingan anak-anak.

Universitas Jambi sebagai salah satu Lembaaga Pendidikan dan merupakan Perguruan Tinggi Negeri terbesar di Provinsi Jambi, melalui Pusat Sudi Pendidikan Masyarakat dibawah Lembaga Penelitian dan Pengabdian Masyarakat turut terpanggil untuk melakasanakan program pendidikan untuk anak-anak SAD. Hasil wawancara pada survey pendahuluan ke Desa Nyogan, anak-anak SAD tersebut memiliki motivasi yang kuat untuk belajar dan menuntut ilmu. Walaupun tidak memiliki sekolah, anak-anak SAD di Dusun Selapik tetap semangat untuk belajar di Sanggar Belajar sederhana yang merupakan teras dari rumah penduduk SAD.

Berdasarkan Undang-undang No.2 Tahun 1989 tentang Sistem Pendidikan Nasional, bahwa bentuk pendidikan dibagi menjadi tiga bentuk yaitu pendidikan formal, pendidikan informal dan pendidikan non formal. Sebagai pelaksanaan ketiga bentuk pendidikan adalah lembaga pemerintah, lembaga keluarga, lembaga keagamaan dan lembaga pendidikan.

Khusus untuk Suku Anak Dalam bentuk pendidikan yang akan diterapkan adalah pendidikan informal. Melalui pendidikan, anak-anak SAD diharapkan menjadi individu yang mempunyai kemampuan dan keterampilan untuk secara mandiri meningkatkan taraf hidupnya baik lahir maupun bathin serta meningkatkan peranannya sebagai individu/pribadi dan warga masyarakat

Kegiatan Pengabdian kepada Masyarakat ini lebih menfokuskan kepada Pendidikan Dasar dengan materi membaca dan berhitung, disamping penididikan karakter. Upaya yang dilakukan untuk terlaksananya kegiatan ini dengan menjalin kerjasama dengan Kepala Desa Nyogan, Karang Taruna dan Temenggung Suku Anak Dalam. Diharapkan dengan adanya kerjasama ini Anak-anak Suku Anak Dalam lebih termotivasi dalam bersekolah nantinya.

\section{METODE PELAKSANAAN}

\section{Metode Pengabdian}

Metode pengabdian yang digunakan yaitu Participatory Rural Apraisal (PRA), yaitu metode pendidikan pada masyarakat. Metode PRA ini memiliki kelebihan, dimana keterlibatan masyarakat secara aktif (sebagai subyek) dan Perguruan Tinggi sebagai fasilitator. 


\subsection{Mekanisme Pelaksanaan Kegiatan Pengabdian Masyarakat}

Merujuk terhadap permasalahan potensial dan tujuan yang diharapkan, rincian program Pengabdian kepada Masyarakat untuk Skim Desa Binaan disesuaikan dengan kondisi masyarakat di Dusun Selapik, Kecamatan Mestong Kabupaten Muaro Jambi, dimana 50\% dari warganya adalah Suku Anak Dalam (SAD). Kegiatan pengabdian difokuskan pada Pendidikan untuk anakanak Suku Anak Dalam.

Dalam pelaksanaanya, metode pengabdian yang digunakan yaitu Participatory Rural Apraisal (PRA), yaitu metode pendidikan pada masyarakat. Metode PRA ini memiliki kelebihan, dimana keterlibatan masyarakat secara aktif (sebagai subyek) dan Perguruan Tinggi sebagai fasilitator.

Kegiatan Pengabdian Pada Masyarakat ini dilaksanakan di Dusun Selapik. Pemilihan lokasi ini didasarkan karena semua anak-anak SAD di Dusun Selapik sama sekali tidak mengikuti sekolah formal, dan hanya belajar di Sanggar Belajar Meraih Mimpi dimana proses belajar mengajar hanya berlangsung selama 3x seminggu dengan tenaga pendidik berasal dari Karang Taruna Desa Nyogan.

Pelaksanaan kegiatan Pengabdian kepada Masyarakat ini meliputi 3 tahapan kegiatan yaitu:

\section{Pendidikan Karakater}

Mengacu pada Sistem Pendidikan Nasional nilai-nilai karakter yang dapat dikembangkan dan ditanamkan kepada peserta didik ada sebanyak 18 macam, namun khusus untuk anakanak SAD, hanya diterapkan sebanyak 15 karakter Nilai-nilai karakter tersebut adalah: (1) religious, (2) jujur, (3) toleransi, (4) disiplin, (5) kerja keras, (6) kreatif, (7) mandiri, (8) rasa ingin tahu, (9) cinta tanah air, (10) menghargai prestasi (11) bersahabat/komunikatif, (12) gemar membaca, (13) peduli lingkungan, (14) peduli social dan (15) tanggung jawab.

\section{Pendidikan Membaca, Menulis dan Berhitung}

Pendidikan membaca, menulis dan berhitung merupakan pendidikan dasar yang harus dimiliki oleh anak-anak SAD, sebagai modal hidup mereka dalam berinteraksi dengan masyarkat nantinya. Minimnya sarana dan prasarana pendidikan yang dimiliki oleh SAD di Dusun Selapik, maka pada kegiatan Pengabdian Pada Masyarakat ini disediakan fasilitas tersebut yang meliputi papan tulis, buku serta alat-alat tulis untuk anak-anak SAD. Tim pengabdian juga memberikan penyuluhan dan pengarahan kepada Karang Taruna dalam mendidik anak-anak SAD nantinya.

\section{Penyuluhan Pentingnya Pendidikan}

Tujuan dari kegiatan Penyulukan Pentingnya Pendidikan diberikan kepada orang tua Suku Anak Dalam, supaya mereka dapat mendukung pendidikan anak-anak mereka kedapannya. Banyaknya anak-anak SAD yang putus sekolah karena kurangnya dukungan dari orang tua. Oleh karena itu maka penyuluhan akan pentingnya pendidikan harus dilakukan.

\section{HASIL YANG DICAPAI}

Kegiatan Pengabdian Masyarakat tentang Peningkatan Kualitas Pendidikan Dalam Rangka Bebas Buta Huruf Untuk Suku Anak Dalam Di Dusun Selapik telah dilakukan dalam beberapa tahapan, diantaranya: 


\section{Sosialisasi Kegiatan Pengabdian Masyarakat}

Sosialisasi dilakukan kepada Kepala Desa dan Perangkat Desa, diantaranya Kepala Dusun dan Ketua RT di Desa Nyogan (Gambar 1). Dusun yang terlibat dalam kegiatan ini adalah Dusun Selapik dimana pada Dusun ini banyak bermukim Suku Anak Dalam (SAD) yang sesuai dengan tujuan Kegiatan Pengabdian ini yang focus pada pendidikan anak-anak SAD.

Berdasarkan hasil sosialisasi dengan Perangkat Desa (Gambar 1), diperoleh beberapa masukan yang sangat penting untuk kelancaran kegiatan pengabdian ini, yaitu:

a. Sebagian besar orang tua SAD di Dusun Selapik kurang mendukung pendidikan untuk anak-anak mereka dan orang tua tersebut cenderung mengajak anak-anaknya untuk membantu kegiatan mereka di ladang. Dari fakta ini, maka perlu dilakukan penyuluhan kepada orang tua SAD di Dusun Selapik karena semua anak-anak mereka tidak ada yang bersekolah.

b. Minimnya sarana dan prasarana pendidikan baik di Dusun Selapik.

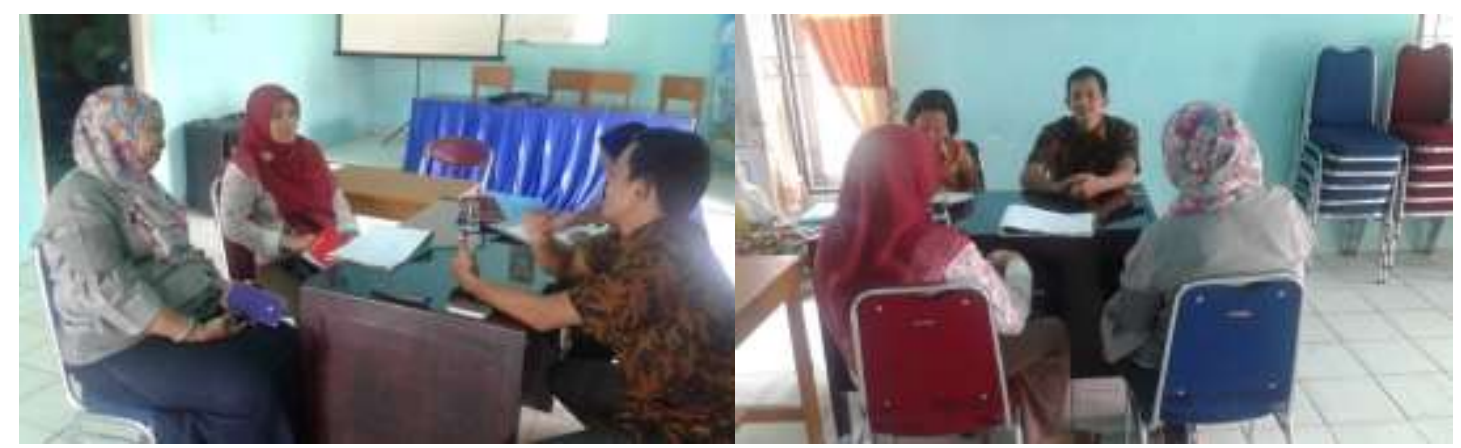

Gambar 1. Sosialisasi Kegiatan Pengabdian dengan Perangkat Desa

\section{Penyuluhan Kepada Orang Tua SAD}

Penyuluhan dilakukan di Dusun Selapik, karena di dusun ini semua anak-anak SAD disini tidak ada yang bersekolah. Tujuan dilakukan penyuluhan adalah untuk memberikan kesadaran kepada para orang tua bahwa pendidikan itu penting. Pendidikan berguna untuk meningkatkan kesejahteraan dan supaya mereka tidak dibodohi sama pihak yang tidak bertanggung jawab karena tidak bisa membaca dan menulis. Kegiatan penyuluhan tersebut diikuti oleh 10 orang ibu-ibu SAD. Mereka sangat senang dan bersemangat dalam mengikuti kegiatan penyuluhan sampai akhir (Gambar 2).

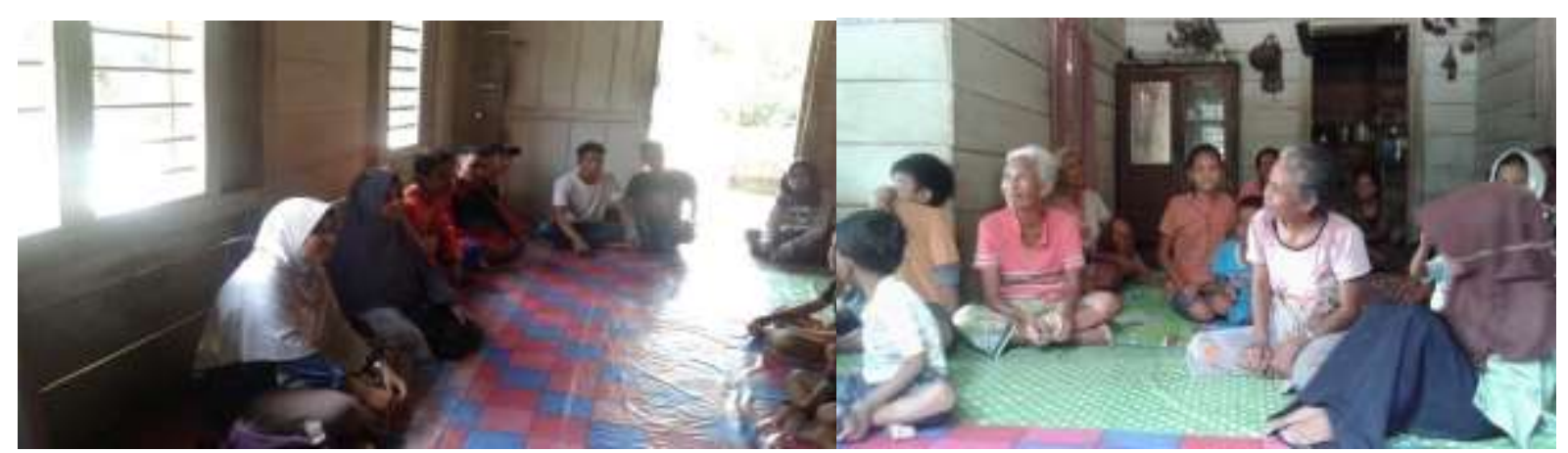

Gambar 2. Penyuluhan pendidikan untuk orang tua SAD di Dusun Selapik 
Pada sesi tanya jawab, ada salah satu orang tua SAD yang menyatakan keluhannya bahwa mereka tidak sanggup untuk menyekolahkan anak-anak mereka karena masalah biaya. Mereka mengatakan “ untuk makan saja susah bu, apalagi untuk sekolah”. Hal ini merupakan masukan yang sangat berharga untuk dilakukan tindak lanjutnya. Kegiatan penyuluhan dilakukan oleh 2 orang narasumber, yaitu Dr. Revis Asra, M.Si dan Ir. Ardiyaningsih Puji Lestari, MP. Ketika penyuluh menanyakan apakah para orang tua SAD mengizinkan anakanaknya bersekolah?. Semua orangtua SAD menjawab ya.

Disamping memberikan penyuluhan kepada orang tua, narasumber juga memberikan penyuluhan kepada anak-anak SAD (Gambar 3). Tujuannya adalah untuk menumbuhkan dan meningkatkan minat dan kesadaran kepada anak-anak SAD bahwa kalau kita bersekolah hidup kita akan lebih baik lagi dan akan mudah dalam mencari pekerjaan. Berdasarkan informasi dari orang tua SAD ada beberapa anak yang malas untu mengikuti sanggar belajar yang dibina oleh Karang Taruna Desa Nyogan. Saat ini pendidikan untuk anak SAD di Dusun Selapik dalam bentuk Sanggar Belajar yang diberi nama "Meraih Mimpi"yang telah berdiri 1 tahun yang lalu. Proses belajar mengajar di sanggar belajar hanya 3x seminggu yaitu pada hari Senin, Rabu dan Jumat, selama 2 jam yaitu mulai dari jam 16.00 - 18,00 WIB.

Pada kesempatan penyuluhan, narasumber juga mendengarkan metode mengajar yang diberikan oleh Karang Taruna. Karang Taruna juga menyampaikan keluhan minimnya sarana dan prasarana pendidikan yang ada. Informasi ini selanjutnya ditindak lanjuti dengan pemberian bantuan sarana dan prasarana pendidikan pada kesempatan berikutnya (Gambar 3).

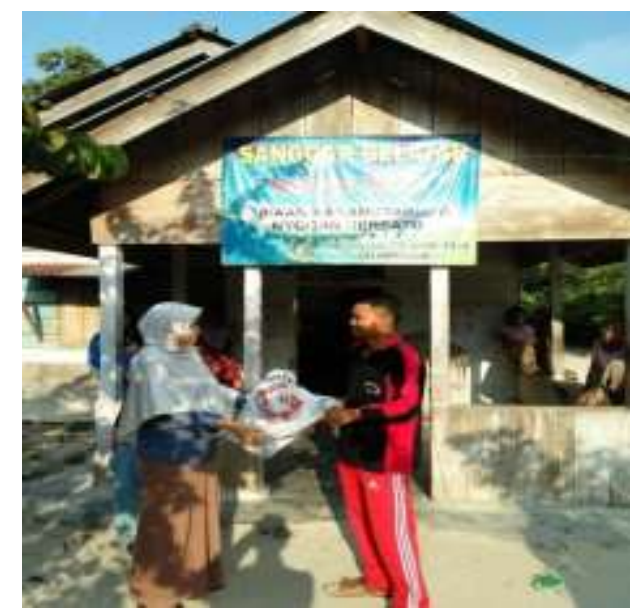

Gambar 3. Pemberian bantuan media pembelajaran dan buku paket kepada Karang Taruna di Dusun Selapik

Selanjutnya narasumber memberikan saran dan masukan kepada guru (anggota Karang Taruna) tentang metode mengajar yang baik. Metode mengajar yang narasumber berikan adalah sebagai berikut:

a. Sebelum mengajar baca salam dulu supaya diridhoi Allah swt.

b. Berikan pendidikan karakter kepada anak dan motivasi anak didik sebelum memberikan pelajaran.

c. Gunakan media pembelajaran supaya lebih menarik dan mudah ditangkap. Hasil penelitian menyebutkan bahwa gambar lebih mudah ditangkap oleh anak disbanding hanya melihat tulisan saja. 
d. Berikan penjelasan yang mudah diterima.

e. Buat kesimpulan pelajaran yang diajarkan.

f. Beri penghargaan kepada yang berprestasi.

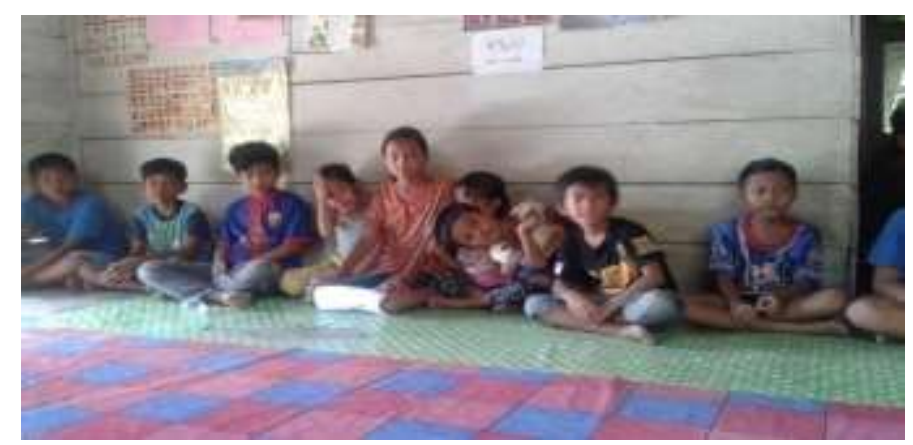

Gambar 4: Anak-anak SAD di Dusun Selapik

\section{Pemberian Bantuan Sarana dan Prasarana Pendidikan.}

Berdasarkan hasil identifikasi kebutuhan, maka dilakukan pemberian bantuan sarana dan prasaran pendidikan. Bantuan yang diberikan kepada anak-anak SAD di Dusun Selapik (Gambar 5). Adapun bantuan yang diberikan adalah sebagai berikut (Tabel 1).

Tabel 1. Pemberian sarana dan prasarana pendidikan untuk anak-anak SAD di Dusun Selapik

\begin{tabular}{clc}
\hline No & \multicolumn{1}{c}{ Bantuan yang diberikan } & Dusun Selapik \\
\hline 1 & Iqra' dan Al Qur'an & V \\
2 & Mukena & V \\
3 & Jilbab & V \\
4 & Sajadah & V \\
5 & Kain sarung & V \\
6 & Pensil & V \\
7 & Penghapus & V \\
8 & Kotak pensil & V \\
9 & Peruncing & V \\
10 & Penggaris & V \\
11 & Spidol & V \\
12 & Penghapus Whiteboard & V \\
13 & Buku Paket SD & V \\
14 & Poster untuk peraga pendidikan & V \\
15 & Map plastik & V \\
\hline
\end{tabular}




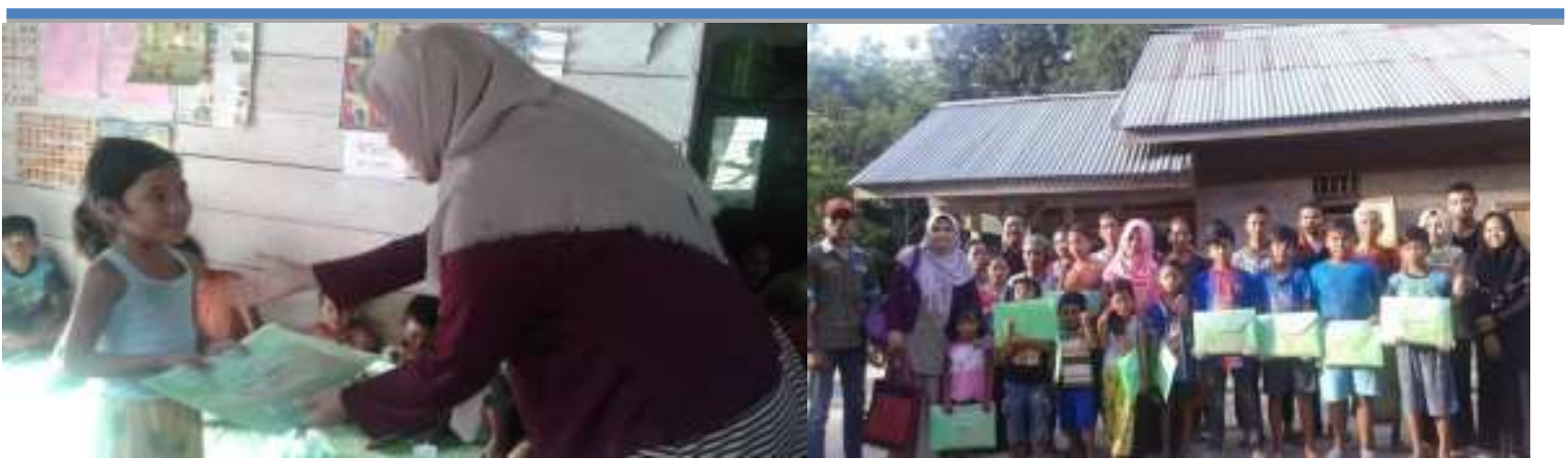

Gambar 5: Pemberian bantuan peralatan pendidikan kepada anak-anak SAD di Dusun Selapik.

\section{Monitoring Kemajuan Pendidkan Anak-anak SAD}

Monitoring dilakukan untuk mengetahui tingkat kemajuan yang diperoleh oleh anak-anak SAD setelah dilakukan penyuluhan dan bantuan sarana pendidikan. Tingkat kemajuan pendidikan anak-anak SAD pada Dusun Selapik dapat dilihat pada Tabel 2. berikut:

Tabel 2. Monitoring Pendidikan Anak-anak SAD sebelum Kegiatan Pengabdian dan Setelah Kegiatan Pengabdian

\begin{tabular}{lll}
\hline No & \multicolumn{1}{c}{ Sebelum Kegiatan Pengabdian } & \multicolumn{1}{c}{ Setelah Kegiatan Pengabdian } \\
\hline 1 & Membaca belum lancar & Lancar walaupun masih mengeja \\
2 & Berhitung belum lancar & Sudah bisa semua \\
3 & Tidak diajarkan pendidikan agama & Sudah diajarkan \\
4 & Buku Paket tidak ada & Sudah ada \\
5 & Peraga Pendidikan tidak ada & Sudah ada \\
6 & Tidak memiliki perlengkapan sholat dan & Sudah ada \\
& mengaji (mukena, jilbab, sajadah, dan kain & \\
& sarung). & \\
7 & Tata cara berwudhuk tidak diajarkan & Dalam proses belajar \\
8 & Tata cara sholat & Bacaan Al fatihah dan surat pendek \\
& dan bacaanya tidak & An Nas sudah bisa \\
& diajarkan & \\
\hline
\end{tabular}

\section{KESIMPULAN}

Berdasarkan kegiatan Pengabdian Kepada Masyarakat tentang Peningkatan Kualitas Pendidikan untuk Suku Anak Dalam di Dusun Selapik dapat diambil kesimpulan:

1. Sosialisasi kepada Kepada Desa dan Aparat Desa telah dilakukan dalam upaya untuk mengetahui kondisi real masyarakat Dusun Selapik.

2. Penyuluhan kepada Orangtua SAD telah menggugah dan menyadarkan mereka akan pentingnya pendidikan untuk anak-anak mereka.

3. Pemberian bantuan kepada Karang Taruna berupa sarana dan prasrana pendidikan, sebagai pedoman dalam mengajar dapat meningkatkan kemampuan Karang Taruna dalam mendidik anak SAD Dusun Selapik. 
4. Pemberian bantuan sarana dan prasarana pendidikan kepada anak-anak SAD meningkatkan pemahaman anak-anak dalam belajar, mengaji dan praktek ibadah.

5. Kemajuan pendidikan anak-anak SAD di Dusun Selapik cukup signifikan dengan adanya kegiatan Pengabdian Masyarakat ini.

\section{DAFTAR PUSTAKA}

Baharudin, E. 2010. Pendidikan Suku Anak Dalam : Suatu Perubahan Dari Paradigma Positivistik Ke Konstruktivisme. Forum Ilmiah Volume 7. Nomor 2. P: 100-104.

Butet Manurung, "Sokola Rimba" Pengalaman Belajar Bersama Orang Rimba, Insist Press, Yogyakarta, 2008

Hidayati, Siti. 2002. Hubungan Antara Tingkat Pendapatan, Sikap Orang Tua Tentang Pendidikan dan Tingkat Pendidikan Anak. Raja Basa Jaya. Bandar Lampung: Unila.

Rahmawanta, Sulis, 2013, "Bersama Masyarakat Membangun Pendidikan". Jurnal Ilmu Pendidikan. Vol 1. No.2 November 2013, Halaman 12-15.

Sutrisno, 2013. "Memahami Anak Putus Sekolah dari Sisi Orang Tua dan Anak".Jurnal Mainstream. Vol. 1 No. 2 Juli 2013, halaman 5-12 